\title{
Design of Cu8Zr5-based bulk metallic glasses
}

Yang, L.; Xia, J.H.; Wang, Q.; Dong, C.; Chen, L.Y.; Ou, X.; Liu, J.F.; Jiang, J.Z.; Klementiev, K.; SaksI, K. Total number of authors:

13

Published in:

Applied Physics Letters

Link to article, DOI:

$10.1063 / 1.2213020$

Publication date:

2006

Document Version

Publisher's PDF, also known as Version of record

Link back to DTU Orbit

Citation (APA):

Yang, L., Xia, J. H., Wang, Q., Dong, C., Chen, L. Y., Ou, X., Liu, J. F., Jiang, J. Z., Klementiev, K., Saksl, K., Franz, H., Schneider, J. R., \& Gerward, L. (2006). Design of Cu8Zr5-based bulk metallic glasses. Applied Physics Letters, 88(24), 241913. https://doi.org/10.1063/1.2213020

\section{General rights}

Copyright and moral rights for the publications made accessible in the public portal are retained by the authors and/or other copyright owners and it is a condition of accessing publications that users recognise and abide by the legal requirements associated with these rights.

- Users may download and print one copy of any publication from the public portal for the purpose of private study or research.

- You may not further distribute the material or use it for any profit-making activity or commercial gain

- You may freely distribute the URL identifying the publication in the public portal 


\title{
Design of $\mathrm{Cu}_{8} \mathrm{Zr}_{5}$-based bulk metallic glasses
}

\author{
L. Yang \\ Laboratory of New-Structured Materials, Department of Materials Science and Engineering, \\ Zhejiang University, Hangzhou 310027, People's Republic of China
}

J. H. Xia, Q. Wang, and C. Dong

State Key Laboratory of Materials Modification, Department of Materials Engineering, Dalian University of Technology, Dalian 116024, People's Republic of China

L. Y. Chen, X. Ou, J. F. Liu, and J. Z. Jiang ${ }^{\text {a) }}$

Laboratory of New-Structured Materials, Department of Materials Science and Engineering, Zhejiang University, Hangzhou 310027, People's Republic of China

K. Klementiev, K. Saksl, H. Franz, and J. R. Schneider

HASYLAB am DESY, Notkestrasse 85, D-22603 Hamburg, Germany

L. Gerward

Department of Physics, Building 307, Technical University of Denmark, DK-2800 Lyngby, Denmark

(Received 7 March 2006; accepted 28 April 2006; published online 14 June 2006)

\begin{abstract}
Basic polyhedral clusters have been derived from intermetallic compounds at near-eutectic composition by considering a dense packing and random arrangement of atoms at shell sites. Using such building units, bulk metallic glasses can be formed. This strategy was verified in the $\mathrm{Cu}-\mathrm{Zr}$ binary system, where we have demonstrated the existence of $\mathrm{Cu}_{8} \mathrm{Zr}_{5}$ icosahedral clusters in $\mathrm{Cu}_{61.8} \mathrm{Zr}_{38.2}, \mathrm{Cu}_{64} \mathrm{Zr}_{36}$, and $\mathrm{Cu}_{64.5} \mathrm{Zr}_{35.5}$ amorphous alloys. Furthermore, ternary bulk metallic glasses can be developed by doping the basic $\mathrm{Cu}-\mathrm{Zr}$ alloy with a minority element. This hypothesis was confirmed in systems $\left(\mathrm{Cu}_{0.618} \mathrm{Zr}_{0.382}\right)_{100-x} \mathrm{Nb}_{x}$, where $x=1.5$ and 2.5 at. \%, and $\left(\mathrm{Cu}_{0.618} \mathrm{Zr}_{0.382}\right)_{98} \mathrm{Sn}_{2}$. The present results may open a route to prepare amorphous alloys with improved glass forming ability. (C) 2006 American Institute of Physics. [DOI: 10.1063/1.2213020]
\end{abstract}

Since the discovery of glassy systems, based on multicomponent alloys, in the early 1990s, bulk metallic glasses (BMGs) have been extensively studied because certain mechanical properties, such as strength, can be significantly improved over their crystalline counterparts. ${ }^{1-11}$ BMGs produced so far usually contain three or more elements. ${ }^{1-3}$ Until now, complex compositions have been considered necessary in order to inhibit crystallization of the liquid phase during cooling of the melt. However, simpler systems should be of great interest, fundamentally as well as technologically, since they would facilitate the atomic-structure determination for a given $\mathrm{BMG}$, which has been a long-standing problem. ${ }^{12-24}$ Originally, the dense-random-packed model was used to describe metallic glasses. ${ }^{25}$ This model is based on the assumption that the glass consists of a random arrangement of spherical atoms (hard spheres) of each element. However, it has also been pointed out that localized, directional chemical bonding and the formation of groups of atoms are relevant factors to theories of glass formation and stability. ${ }^{26}$ The local structure is well defined and similar to that of the crystalline form of the material. Recently, a topological model for metallic glass formation was proposed. ${ }^{27,28}$ According to that model, a solute occupying either substitutional or interstitial sites in the host lattice can destabilize the lattice by producing a critical internal strain. Besides the structural models mentioned above, several criteria for structural stability of a BMG have been suggested: (1) large value of the reduced glass transition temperature $T_{g} / T_{l}$, where $T_{g}$ is the glass transition temperature and $T_{l}$ is the liquidus

\footnotetext{
a) Authors to whom correspondence should be addressed; jiangjz@zju.edu.cn
} and dong@dlut.edu.cn temperaure; $^{29}$ (2) three empirical rules for a large supercooled liquid region: (a) multicomponent system, (b) significant differences in atomic size, and (c) negative heats of mixing among the main constituent atoms; ${ }^{1,3}$ (3) high gamma value, $\gamma=T_{x} /\left(T_{g}+T_{l}\right)$, where $T_{x}$ is crystallization temperature $;^{30}(4)$ interaction between the Fermi surface and the Brillouin zone in a nearly-free-electron model; ${ }^{31}(5)$ the critical concentration of a solute element required for amorphization decreases, reaches a minimum, and then increases with increasing ratio between the size of the solute and the solvent atoms; ${ }^{27,32,33}(6)$ there is an optimum ratio $R^{*}$ between the size of the solute atom and the average size of the surrounding solvent atoms for dense packing. ${ }^{28,34}$ In spite of the criteria mentioned above, the design of alloys with a high glass forming ability (GFA) remains to a large extent unpredictable due to lack of understanding of the local atomic structure. Although polyhedral clusters have been revealed in some metallic glasses, ${ }^{12-20}$ more efforts are still needed to uncover the atomic structure of a given BMG and to predict compositions with high GFA. In this letter, we report a method of designing appropriate polyhedral units to simulate the local atomic structure of binary $\mathrm{Cu}-\mathrm{Zr}$ amorphous alloys. Our method predicts the formation of $\mathrm{Cu}_{8} \mathrm{Zr}_{5}$-based BMGs, in which the polyhedral units are indeed experimentally detected.

We have chosen the $\mathrm{Cu}-\mathrm{Zr}$ binary system as a prototype because of three reasons: (1) it has a wide composition range forming metallic glasses, (2) BMGs can be formed in this system, $^{35}$ and (3) its phase diagram is known. There are several intermetallic compounds, $\mathrm{Cu}_{5} \mathrm{Zr}, \mathrm{Cu}_{51} \mathrm{Zr}_{41}, \mathrm{Cu}_{8} \mathrm{Zr}_{3}$, $\mathrm{Cu}_{10} \mathrm{Zr}_{7}, \mathrm{CuZr}$, and $\mathrm{CuZr}_{2}$. The Wykoff sites of $\mathrm{Cu}$ and $\mathrm{Zr}$ in these compounds are listed in Pearson's handbook. ${ }^{36}$ Taking 


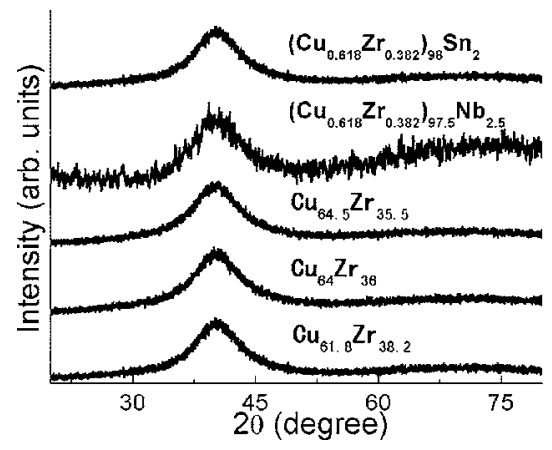

FIG. 1. X-ray diffraction patterns for the as-spun $\mathrm{Cu}-\mathrm{Zr}$ metallic glasses and as-cast $3 \mathrm{~mm}\left(\mathrm{Cu}_{0.618} \mathrm{Zr}_{0.382}\right)_{97.5} \mathrm{Nb}_{2.5}$ and $\left(\mathrm{Cu}_{0.618} \mathrm{Zr}_{0.382}\right)_{98} \mathrm{Sn}_{2}$ BMG rods.

each Wykoff site as the center, 35 polyhedral one-shell clusters can be constructed using the computer program ATOMS. ${ }^{37}$ In order to select appropriate clusters as basic units for the forming of BMGs, three factors have been considered: (1) dense packing, (2) random arrangement of atoms at shell sites, and (3) near-eutectic composition. Dense packing is an essential criterion for the atomic structure of BMGs. ${ }^{38}$ Suppose that the radius of the center atom in a cluster is $r_{0}$ and that the average radius of the shell atoms is $r_{1}$, according to Miracle $^{28}$ and Miracle and Sanders, ${ }^{34}$ the ratio $R=r_{0} / r_{1}$ should be within $10 \%$ from the optimum value $R^{*}$ for close packing. Clusters with less than ten atoms were not considered in the present work since $r_{\mathrm{Cu}} / r_{\mathrm{Zr}}=0.79$, which is $10 \%$ larger than the optimum value $R^{*}=0.71$ for a solute atom surrounded by nine solvent atoms. Based on a random arrangement of atoms, the concentration of atoms of the same kind on shell sites might lead to instability of the cluster. Finally, 11 clusters out of a total of 35 were selected for further study. There are four eutectic points of interest in the present work: $\mathrm{Cu}_{61.8} \mathrm{Zr}_{38.2}, \mathrm{Cu}_{56} \mathrm{Zr}_{44}, \mathrm{Cu}_{45.7} \mathrm{Zr}_{54.3}$, and $\mathrm{Cu}_{27.6} \mathrm{Zr}_{72.4}$. As it turns out, three of our selected clusters, namely, $\mathrm{Cu}_{8} \mathrm{Zr}_{5}\left(\mathrm{Cu}_{61.5} \mathrm{Zr}_{38.5}\right), \mathrm{Cu}_{6} \mathrm{Zr}_{5}\left(\mathrm{Cu}_{54.5} \mathrm{Zr}_{45.5}\right)$, and $\mathrm{Cu}_{5} \mathrm{Zr}_{6}\left(\mathrm{Cu}_{45.5} \mathrm{Zr}_{54.5}\right)$, are very close to eutectic compositions. BMG rods have recently been synthesized with compositions $\mathrm{Cu}_{64.5} \mathrm{Zr}_{35.5}$ (with a diameter of $2 \mathrm{~mm}$ ), $\mathrm{Cu}_{64} \mathrm{Zr}_{36}$ (with a thickness of $2 \mathrm{~mm}$ ), $\mathrm{Cu}_{60} \mathrm{Zr}_{40}$ (with a diameter of $1 \mathrm{~mm}$ ), and $\mathrm{Cu}_{45} \mathrm{Zr}_{55}$ (with a diameter of $1.5 \mathrm{~mm}$ ). ${ }^{35}$ This fact strongly suggests that polyhedral clusters are the main building units of $\mathrm{Cu}-\mathrm{Zr}$ BMGs with near-eutectic compositions. Two key questions will be addressed in the present work: (1) Do polyhedral clusters exist in BMGs based on the $\mathrm{Cu}-\mathrm{Zr}$ system? (2) If yes, will it be possible to predict other cluster-based BMGs, in which the value of $R$ is made close to $R^{*}$ by alloying with a minority element? To answer these questions, three compositions, $\mathrm{Cu}_{61.8} \mathrm{Zr}_{38.2}$ (eutectic composition), $\mathrm{Cu}_{64} \mathrm{Zr}_{36}$, and $\mathrm{Cu}_{64.5} \mathrm{Zr}_{35.5}$, were selected. As will be shown below, extended $x$-ray absorption fine structure (EXAFS) measurements at the $\mathrm{Cu}$ and $\mathrm{Zr} K$ absorption edges indicate that the metallic glasses indeed contain $\mathrm{Cu}_{8} \mathrm{Zr}_{5}$ icosahedral clusters. Moreover, BMG rods with a diameter of $3 \mathrm{~mm}$ could be produced with a minor addition of $\mathrm{Nb}$ and Sn, making $R$ closer to $R^{*}$.

$\mathrm{Cu}-\mathrm{Zr}$ ingots with compositions $\mathrm{Cu}_{61.8} \mathrm{Zr}_{38.2}, \mathrm{Cu}_{64} \mathrm{Zr}_{36}$, and $\mathrm{Cu}_{64.5} \mathrm{Zr}_{35.5}$ were prepared by arc melting of high-purity metals $(99.8 \%-99.9 \%)$. Ribbons with a cross section area of $0.03 \times 2.5 \mathrm{~mm}^{2}$ were obtained by single-roller melt spinning at a wheel surface velocity of $30 \mathrm{~m} / \mathrm{s}$ in purified argon atmosphere. The x-ray diffraction (XRD) patterns (cf. Fig. 1)

Downloaded 17 Jun 2010 to 192.38.67.112. Redistribution subject
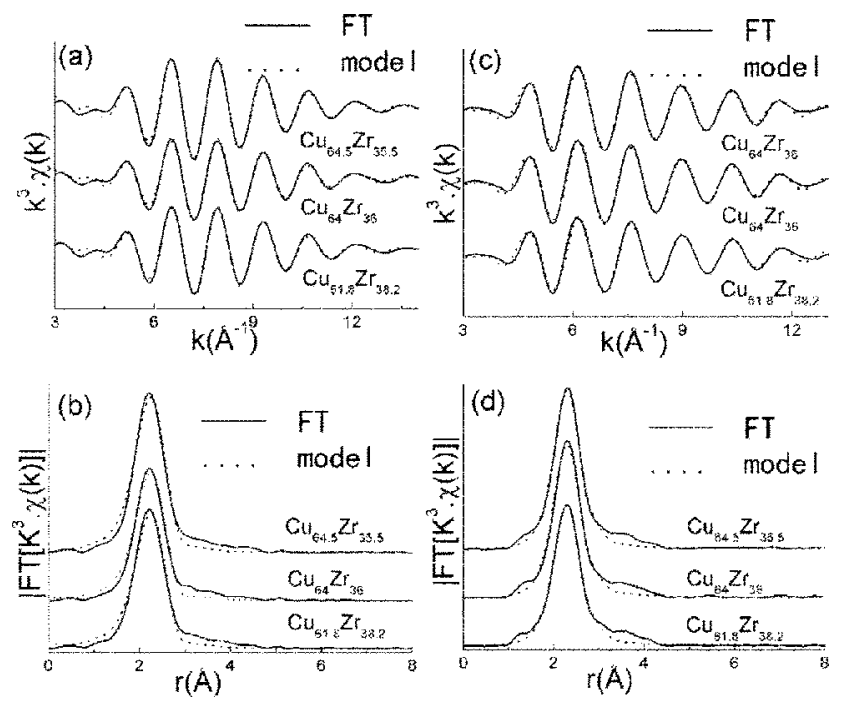

FIG. 2. EXAFS spectra in $k$ space and $r$ space for as-spun $\mathrm{Cu}-\mathrm{Zr}$ metallic glasses. Full curves denote experimental measurements; dotted curves are the result of the fit using the model described in the text. (a) and (b) at the $\mathrm{Cu} K$ edge; (c) and (d) at the $\mathrm{Zr} K$ edge.

consist of a broad peak at $2 \theta \approx 40^{\circ}$, confirming the amorphous state. EXAFS measurements at photon energies corresponding to the $\mathrm{Cu}$ and $\mathrm{Zr} K$ absorption edges were performed at the HASYLAB synchrotron radiation source (beamline X1) in transmission. Standard data evaluation was carried out using the VIPER and WINXAS programs. ${ }^{39}$ In the fitting process, the FEFF- 8 code $^{40}$ was used to calculate scattering amplitudes and phases.

In Fig. 2 we show $\mathrm{Cu}$ and $\mathrm{Zr} K$-edge EXAFS spectra for as-spun $\mathrm{Cu}_{61.8} \mathrm{Zr}_{38.2}, \mathrm{Cu}_{64} \mathrm{Zr}_{36}$, and $\mathrm{Cu}_{64.5} \mathrm{Zr}_{35.5}$ metallic glasses. $\mathrm{A} \mathrm{Cu}_{9} \mathrm{Zr}_{4}$ icosahedral cluster with a $\mathrm{Cu}$ atom at the center position and a $\mathrm{Cu}_{8} \mathrm{Zr}_{5}$ icosahedral cluster with a $\mathrm{Zr}$ atom at the center (Fig. 3) were designed as models for the fits to the experimental $\mathrm{Cu}$ and $\mathrm{Zr} K$-edge spectra, respectively. $\mathrm{Cu}-\mathrm{Zr}$ and $\mathrm{Zr}-\mathrm{Cu}$ bond distances were forced to be equal during the fitting. As shown in Fig. 2, the observed $\mathrm{Cu}$ and $\mathrm{Zr} K$-edge spectra in $k$ and $r$ spaces are well described by the fitting curves. The EXAFS fitting parameters are given in Table I. It is clear that the $\mathrm{Cu}$ center atom is indeed surrounded by about five $\mathrm{Zr}$ and seven $\mathrm{Cu}$ atoms, forming a $\mathrm{Cu}_{8} \mathrm{Zr}_{5}$ icosahedral cluster, although the $\mathrm{Cu}_{9} \mathrm{Zr}_{4}$ model was used as the initial input. Slight differences between the $\mathrm{Cu}-\mathrm{Cu}$ and $\mathrm{Cu}-\mathrm{Zr}$ bond lengths indicate a distorted icosahedral cluster with a $\mathrm{Cu}$ atom at the center site. On the other hand, the $\mathrm{Zr}$ atom is found to have only about four $\mathrm{Cu}$ atoms
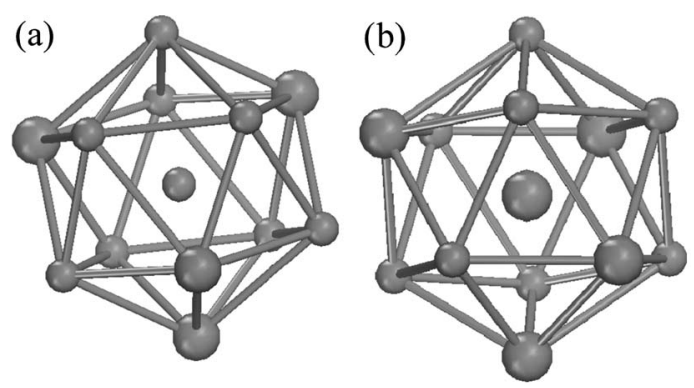

FIG. 3. Icosahedral models for EXAFS simulation. Small spheres are $\mathrm{Cu}$ atoms and large spheres are $\mathrm{Zr}$ atoms. (a) $\mathrm{Cu}$ at center position for simulation of $\mathrm{Cu} K$-edge spectra; (b) $\mathrm{Zr}$ at center position for simulation of $\mathrm{Zr}$ $K$-edge spectra. 
TABLE I. EXAFS results. $N$ is the coordination number, $r_{i-j}$, where $i$ and $j$ are $\mathrm{Cu}$ and/or $\mathrm{Zr}$, is the interatomic distance, and $\sigma^{2}$ is the mean-square relative displacement. In order to minimize the number of parameters, a single energy shift was varied for each absorption edge.

\begin{tabular}{|c|c|c|c|c|c|c|c|}
\hline \multirow[b]{2}{*}{ Alloy } & \multirow{2}{*}{$\begin{array}{l}\text { Atom at } \\
\text { center }\end{array}$} & \multicolumn{2}{|c|}{$r_{i-j}(\AA)$} & \multicolumn{2}{|c|}{$N$} & \multicolumn{2}{|c|}{$\sigma^{2}\left(10^{-3} \AA\right)$} \\
\hline & & $-\mathrm{Cu}$ & $-\mathrm{Zr}$ & $-\mathrm{Cu}$ & $-\mathrm{Zr}$ & $-\mathrm{Cu}$ & $-\mathrm{Zr}$ \\
\hline \multirow[t]{2}{*}{$\mathrm{Cu}_{61.8} \mathrm{Zr}_{38.2}$} & $\mathrm{Cu}$ & $2.53(2)$ & 2.68(7) & $7(2)$ & $5(2)$ & $26(4)$ & 13(1) \\
\hline & $\mathrm{Zr}$ & 2.68(7) & $3.01(3)$ & $4(2)$ & $8(2)$ & $9(1)$ & $29(1)$ \\
\hline \multirow[t]{2}{*}{$\mathrm{Cu}_{64} \mathrm{Zr}_{36}$} & $\mathrm{Cu}$ & $2.53(2)$ & 2.69(7) & $7(2)$ & $5(3)$ & 26(4) & $12(1)$ \\
\hline & $\mathrm{Zr}$ & $2.69(7)$ & $3.01(3)$ & $4(2)$ & $8(2)$ & $9(1)$ & $28(2)$ \\
\hline \multirow[t]{2}{*}{$\mathrm{Cu}_{64.5} \mathrm{Zr}_{35.5}$} & $\mathrm{Cu}$ & $2.53(2)$ & 2.69(7) & $7(3)$ & $5(3)$ & $24(4)$ & $13(1)$ \\
\hline & $\mathrm{Zr}$ & $2.69(7)$ & $3.00(3)$ & $4(2)$ & $8(2)$ & $9(1)$ & $27(2)$ \\
\hline
\end{tabular}

as nearest neighbors, while the $\mathrm{Zr}-\mathrm{Zr}$ coordination number is about 8 . The results above imply that $\mathrm{Cu}$ atoms are situated at the center sites of $\mathrm{Cu}_{8} \mathrm{Zr}_{5}$ icosahedral clusters, while the $\mathrm{Zr}$ atoms are located at the shell sites. This is understandable, since the radius of the $\mathrm{Cu}$ atom $(1.28 \AA)$ is less than the radius of the $\mathrm{Zr}$ atom $(1.61 \AA)$. Various ways of combining $\mathrm{Cu}$-centered $\mathrm{Cu}_{8} \mathrm{Zr}_{5}$ icosahedral clusters may result in slight differences in the composition of the alloy. Thus, our results strongly support the hypothesis above that the atomic structure of $\mathrm{Cu}_{61.8} \mathrm{Zr}_{38.2}, \mathrm{Cu}_{64} \mathrm{Zr}_{36}$, and $\mathrm{Cu}_{64.5} \mathrm{Zr}_{35.5}$ amorphous alloys is mainly made up of $\mathrm{Cu}_{8} \mathrm{Zr}_{5}$ icosahedral clusters.

Adding a third element, having a larger atomic radius than $\mathrm{Cu}$, at shell sites of the $\mathrm{Cu}_{8} \mathrm{Zr}_{5}$ icosahedral clusters should result in a higher $R$ value and thereby a higher GFA. $^{28,34}$ Consequently, one would expect a whole class of $\mathrm{Cu}_{8} \mathrm{Zr}_{5}$-based BMGs according to our model. In order to test this hypothesis, we have selected $\mathrm{Nb}$ (atomic radius of $1.47 \AA$ ) and $\mathrm{Sn}$ (atomic radius of $1.51 \AA$ ) as the minority elements and prepared amorphous alloys according to the formulas $\left(\mathrm{Cu}_{0.618} \mathrm{Zr}_{0.382}\right)_{98.5} \mathrm{Nb}_{1.5}, \quad\left(\mathrm{Cu}_{0.618} \mathrm{Zr}_{0.382}\right)_{97.5} \mathrm{Nb}_{2.5}$, and $\left(\mathrm{Cu}_{0.618} \mathrm{Zr}_{0.382}\right)_{98} \mathrm{Sn}_{2}$. It is found that $\mathrm{BMG}$ rods with a diameter of $3 \mathrm{~mm}$ could indeed be produced (Fig. 1) by copper mold.

In conclusion, basic polyhedral clusters have been derived for intermetallic compounds at near-eutectic composition by considering a dense packing and random arrangement of atoms at shell sites. Using such building units, BMGs can be formed. This strategy was verified in the $\mathrm{Cu}-\mathrm{Zr}$ binary system, where we have demonstrated the existence of $\mathrm{Cu}_{8} \mathrm{Zr}_{5}$ icosahedral clusters in $\mathrm{Cu}_{61.8} \mathrm{Zr}_{38.2}, \mathrm{Cu}_{64} \mathrm{Zr}_{36}$, and $\mathrm{Cu}_{64.5} \mathrm{Zr}_{35.5}$ amorphous alloys. Furthermore, ternary BMGs can be developed by doping the basic $\mathrm{Cu}-\mathrm{Zr}$ alloy with a minority element. This hypothesis was confirmed in systems $\left(\mathrm{Cu}_{0.618} \mathrm{Zr}_{0.382}\right)_{100-x} \mathrm{Nb}_{x}$, where $x=1.5$ and 2.5 at. $\%$, and $\left(\mathrm{Cu}_{0.618} \mathrm{Zr}_{0.382}\right)_{98} \mathrm{Sn}_{2}$. The present results may open a route to prepare amorphous alloys with improved GFA.

The authors would like to thank HASYLAB in Hamburg, Germany, BSRF in Beijing and NSRL in Hefei, P.R. China, MAX-Lab in Lund, Sweden, APS in Chicago, U.S.A., and SPring-8 and KEK in Japan for use of the synchrotron radiation facilities. Financial support from the National Natural Science Foundation of China (Grants Nos. 50341032, 50425102, 50271012, and 50401020), the Ministry of Education of China (Grant Nos. 2.005E+10 and 200555), Zhejiang University, and Dalian University of Technology is gratefully acknowledged.
${ }^{1}$ A. Inoue, Bulk Amorphous Alloys 1 and 2 (Trans Tech, Zurich, Switzerland, 1998).

${ }^{2}$ W. L. Johnson, MRS Bull. 24, 42 (1999).

${ }^{3}$ A. Inoue, Acta Mater. 48, 279 (2000).

${ }^{4}$ Y. He, S. J. Poon, and G. J. Shiflet, Science 241, 1640 (1988).

${ }^{5}$ A. L. Greer, Science 267, 1947 (1995).

${ }^{6}$ X. P. Tang, U. Geyer, R. Busch, W. L. Johnson, and Y. Wu, Nature (London) 402, 160 (1999).

${ }^{7}$ G. He, J. Eckert, W. Loser, and L. Schultz, Nat. Mater. 2, 33 (2003).

${ }^{8}$ A. Inoue, B. L. Shen, H. Koshiba, H. Kato, and A. R. Yavari, Nat. Mater. 2, 661 (2003).

${ }^{9}$ Z. P. Liu, C. T. Liu, J. R. Thompson, and W. D. Porter, Phys. Rev. Lett. 92, 245503 (2004).

${ }^{10}$ J. Schroers and W. L. Johnson, Phys. Rev. Lett. 93, 255506 (2004).

${ }^{11}$ J. Das, M. B. Tang, K. B. Kim, R. Theissmann, F. Baier, W. H. Wang, and J. Eckert, Phys. Rev. Lett. 94, 205501 (2005); B. Zhang, D. Q. Zhao, M. X. Pan, W. H. Wang, and A. L. Greer, ibid. 94, 205502 (2005); Y. Wang, Y. Z. Fang, T. Kikegawa, C. Lathe, K. Saksl, H. Franz, J. R. Schneider, L. Gerward, F. M. Wu, J. F. Liu, and J. Z. Jiang, ibid. 95, 155501 (2005).

${ }^{12}$ D. R. Nelson and F. Spaepen, Solid State Phys., Adv. Res. Appl. 42, 1 (1989).

${ }^{13}$ J. P. K. Doye and D. J. Wales, Science 271, 484 (1996).

${ }^{14}$ F. Spaepen, Nature (London) 408, 781 (2000).

${ }^{15}$ D. D. Kofalt, S. Nanao, T. Egami, K. M. Wong, and S. J. Poon, Phys. Rev. Lett. 57, 114 (1986).

${ }^{16}$ L. Q. Xing, T. C. Hufnagel, J. Eckert, W. Löser, and L. Schultz, Appl. Phys. Lett. 77, 1970 (2000)

${ }^{17}$ J. Saida, N. Matsushita, and A. Inoue, Appl. Phys. Lett. 79, 412 (2001); M. W. Chen, I. Dutta, T. Zhang, A. Inoue, and T. Sakurai, ibid. 79, 42 (2001).

${ }^{18}$ T. Takagi, T. Ohkubo, Y. Hirotsu, B. S. Murty, K. Hono, and D. Shindo, Appl. Phys. Lett. 79, 485 (2001).

${ }^{19}$ K. Saksl, H. Franz, P. Jóvári, K. Klementiev, E. Welter, A. Ehnes, J. Saida, A. Inoue, and J. Z. Jiang, Appl. Phys. Lett. 83, 3924 (2003); L. Yang, J. Z. Jiang, T. Liu, T. D. Hu, and T. Uruga, ibid. 87, 061918 (2005).

${ }^{20}$ W. K. Luo, H. W. Sheng, F. M. Alamgir, J. M. Bai, J. H. He, and E. Ma, Phys. Rev. Lett. 92, 145502 (2004).

${ }^{21}$ J. Jonsson and H. C. Anderson, Phys. Rev. Lett. 60, 2295 (1988).

${ }^{22}$ F. Yonezawa, Solid State Phys. 45, 179 (1991).

${ }^{23}$ A. S. Clarke and H. Jonsson, Phys. Rev. E 47, 3975 (1993).

${ }^{24}$ S. Cozzini and M. Ronchetti, Phys. Rev. B 53, 12040 (1996).

${ }^{25}$ G. D. Scott, Nature (London) 188, 908 (1960); J. D. Bernal and J. Mason, ibid. 188, 910 (1960); M. H. Cohen and D. Turnbull, ibid. 203, 964 (1964); J. L. Finney, ibid. 266, 309 (1977).

${ }^{26}$ P. H. Gaskell, Nature (London) 276, 484 (1978); P. H. Gaskell, J. NonCryst. Solids 32, 207 (1979).

${ }^{27}$ O. N. Senkov and D. B. Miracle, J. Non-Cryst. Solids 317, 34 (2003).

${ }^{28}$ D. B. Miracle, Nat. Mater. 3, 697 (2004).

${ }^{29}$ D. Turnball and J. Fisher, J. Chem. Phys. 17, 71 (1949).

${ }^{30}$ Z. P. Lu and C. T. Liu, Acta Mater. 50, 3501 (2002).

${ }^{31}$ S. R. Nagel and J. Tauc, Phys. Rev. Lett. 35, 380 (1975).

${ }^{32}$ T. Egami and Y. Waseda, J. Non-Cryst. Solids 64, 113 (1984).

${ }^{33}$ D. B. Miracle and O. N. Senkov, Mater. Sci. Eng., A 347, 50 (2003).

${ }^{34}$ D. B. Miracle and W. S. Sanders, Philos. Mag. 83, 2409 (2003).

${ }^{35}$ D. H. Xu, B. Lohwongwatana, G. Duan, W. L. Johnson, and C. Garland, Acta Mater. 52, 2621 (2004); W. Zhang and A. Inoue, Mater. Trans., JIM 45, 584 (2004); D. Wang, Y. Li, B. B. Sun, M. L. Sui, K. Lu, and E. Ma, Appl. Phys. Lett. 84, 4029 (2004).

${ }^{36} \mathrm{P}$. Villars and L. D. Calvert, Pearson's Handbook of Crystallographic Data for Intermetallic Phases (American Society for Metals, Metals Park, OH, 1985).

${ }^{37}$ B. Ravel, J. Synchrotron Radiat. 8, 314 (2001).

${ }^{38}$ F. Spaepen, J. Non-Cryst. Solids 31, 207 (1978).

${ }^{39}$ K. V. Klementiev, vIPER for wINDOws, www.desy.de/ klmn/viper.html; K. V. Klementev, J. Phys. D 34, 209 (2001) and T. J. Ressler, J. Synchrotron Radiat. 5, 118 (1998).

${ }^{40}$ A. L. Ankudinov, B. Ravel, J. J. Rehr, and S. D. Conradson, Phys. Rev. B 58, 7565 (1998). To account for many-electron excitations, we took the many-body factors $S_{o}^{2}$ as calculated by FEFF. The instrumental broadening was included into FEFF calculations by adjusting the imaginary part of the scattering potential in a way that we could extract the true coordination numbers $(N=12)$ from the reference EXAFS spectra of pure $\mathrm{Cu}$ and $\mathrm{Zr}$ foils. Then the same broadening was used for the calculations of interest. 